\title{
ANALISIS KESULITAN BELAJAR SISWA PADA POKOK BAHASAN LINGKARAN DI MTS SWASTA LHULO
}

\author{
Paskoni $^{1}$, Eline Yanty Putri Nasution ${ }^{2}$, Rahmi Putri $^{3}$ \\ 1,2,3 IAIN Kerinci \\ *elineyantyputrinasution@iainkerinci.ac.id
}

\begin{abstract}
This study aims to determine the level of difficulty learning mathematics circle material and its causes. The key informants in this study were students of class VIII in MTs Private Lhulo, Bukit Kerman District. This research is a qualitative descriptive study. The methods are observation, interview, questionnaire, and documentation. The results of the study showed that the level of difficulty learning the subject of the circle in the class VIII students in Lhulo Private MTs was relatively low. Factors causing the learning difficulties of mathematics in circle subjects in class VIII in MTs Lhulo Private are: lack of use of learning media, application of inappropriate methods, lack of fulfillment of learning needs, low level of student intelligence, and low motivation of students in learning mathematics. Efforts to overcome the difficulties of learning mathematics on the subject of the circle in class VIII students at Lhulo Private MTs include: making a study schedule at home, giving guidance to students, using varied methods, using the method of complete learning and the procurement of supporting facilities.
\end{abstract}

Key Words: Difficulty Learning, Mathematics, Circle.

\begin{abstract}
Abstrak: Penelitian ini bertujuan untuk mengetahui tingkat kesulitan belajar matematika materi lingkaran dan faktor penyebabnya. Informan kunci dalam penelitian ini adalah siswa kelas VIII MTs Swasta Lhulo Kecamatan Bukit Kerman. Penelitian ini merupakan penelitian deskriptif kualitatif. Metodenya adalah observasi, wawancara, angket, dan dokumentasi. Hasil penelitian menunjukkan bahwa tingkat kesulitan belajar matematika pokok bahasan lingkaran pada siswa kelas VIII di MTs Swasta Lhulo tergolong rendah. Faktor penyebab terjadinya kesulitan belajar matematika pokok bahasan lingkaran pada siswa kelas VIII di MTs Swasta Lhulo yakni: kurangnya penggunaan media pembelajaran, penerapan metode yang kurang tepat, kurang terpenuhinya kebutuhan belajar, rendahnya tingkat intelegensi siswa, dan rendahnya motivasi siswa dalam belajar matematika.Upaya mengatasi kesulitan belajar matematika pokok bahasan lingkaran pada siswa kelas VIII di MTs Swasta Lhulo, diantaranya ialah : membuat jadwal belajar di rumah, memberikan bimbingan pada siswa, menggunakan metode bervariasi, menggunakan metode belajar tuntas dan pengadaan fasilitas penunjang.
\end{abstract}

Kata Kunci: kesulitan belajar; matematika; lingkaran.

\section{PENDAHULUAN}

Matematika merupakan salah satu mata pelajaran yang diajarkan pada jenjang pendidikan dasar dan menengah bahkan hingga ke perguruan tinggi. Namun, pada realitanya matematika adalah salah satu mata pelajaran yang dihindari, takuti bahkan 
dibenci, bahkan sampai sekarang pun masih sering dianggap sebagai sesuatu yang sangat menyeramkan. Banyak siswa yang tidak berminat, tidak semangat dan enggan memberikan respon saat belajar Matematika (Nasution, Pebrianti \& Putri, 2020).

Dari hasil survey Program for International Student Assessment (PISA) tahun 2015 mengadakan survei tentang kemampuan siswa dan sistem pendidikan yang menunjukkan bahwa kemampuan matematika siswa-siswi di Indonesia menduduki peringkat 65 dari 72 negara alias kesembilan dari bawah dengan skor 385 . Hal ini menunjukan bahwa siswa masih mengalami kesulitan dalam menyelesaikan persoalan yang berkaitan dengan pembelajaran matematika.

Berdasarkan hasil wawancara awal yang peneliti lakukan pada tanggal 16 September 2019 di MTs Swasta Lhulo Kecamatan Bukit Kerman, diketahui bahwa sebagian besar siswa masih menganggap bahwa matematika merupakan pelajaran yang sukar dan kurang disenangi oleh siswa. Hal tersebut disebabkan oleh banyak faktor, antara lain: tidak mengetahui tujuan, manfaat, hakekat, dan fungsi matematika itu sendiri. Oleh karena itu, guru harus membantu kesulitan yang dihadapi siswa tersebut.

Terdapat banyak peserta didik yang setelah belajar matematika tidak mampu memahami bahkan pada bagian yang paling sederhana sekalipun, banyak konsep yang dipahami secara keliru sehingga matematika dianggap sebagai ilmu yang sukar, ruwet, dan sulit. Dengan demikian, ketika mempelajari matematika salah satu yang harus ditekankan kepada siswa adalah bisa memahami konsep, maka siswa akan mengalami kesulitan dalam belajar matematika baik dari materi yang termudah ataupun yang tersulit. Hal ini sesuai dengan Standar Isi Mata Pelajaran Matematika, yaitu pembelajaran matematika diharapkan dapat menumbuhkan dan mengembangkan kemámpuan pemahaman konsep matematis siswa.

Menurut Sardiman, faktor penyebab timbulnya kesulitan bagi siswa dalam mempelajari matematika karena karakteristik matematika itu sendiri yakni konsep-konsep umumnya bersifat abstrak. Faktor lain adalah kebiasaan hanya menerapkan metode ceramah dalam pelaksanaan belajar serta kurangnya kemampuan guru untuk menghadirkan pendekatan belajar yang tepat untuk memotivasi siswa serta melibatkannya dalam proses pembelajaran (Sardiman, 2001).

Kesulitan-kesulitan yang dialami oleh siswa tersebut harus diketahui guru untuk kelancaran proses belajar dan mengajar selanjutnya. Namun guru tidak dapat mengambil keputusan dalam membantu siswanya yang mengalami kesulitan belajar jika guru tidak mengetahui di mana letak kesulitannya. Oleh karena seorang guru perlu mengetahui kesulitan siswa dalam belajar matematika dan juga mengetahui penyebabnya. Selain itu, apabila diketahui jenis kesulitan yang dialami siswa maka dapat dijadikan bahan pertimbangan oleh guru untuk melakukan perbaikan mengajar. 
Alasan penulis melakukan penelitian ini adalah untuk melokalisasi jenis kesulitan belajar siswa kelas VIII MTs Swasta Lhulo Kecamatan Bukit Kerman pada pokok bahasan lingkaran agar ada penanganan khusus dari pihak guru maupun sekolah, sehingga dalam hal ini peneliti tertarik untuk menganalisais kesulitan siswa kelas VIII MTs Swasta Lhulo Kecamatan Bukit Kerman yang berkaitan dengan jenis dan faktor yang didapatkan siswa pada materi lingkaran serta jenis-jenis kesulitan belajar lainnya pada materi lingkaran untuk diinformasikan kepada guru dan pihak sekolah agar dapat dijadikan bahan untuk menentukan penanganan atas dasar apa yang telah dibentuk sebelumnya.

Hal ini sejalan dengan pendapat Hudojo (2005) yang mengemukakan bahwa: "Apabila siswa mengalami kesulitan dalam mempelajari materi lingkaran maka siswa akan mengalami kesulitan dalam mempelajari materi materi yang lain yang berhubungan dengan materi lingkaran."

Berdasarkan uraian di atas, maka penulis tertarik dan dan termotivasi untuk mengadakan penelitian lebih mendalam dan mengkajinya dalam sebuah judul: "Analisis Kesulitan Belajar Siswa pada Pokok Bahasan Lingkaran di MTs Swasta Lhulo".

Berdasarkan pemaparan latar belakang masalah yang penulis tuangkan sebelumnya, adapun permasalahan yang dikaji dalam penelitian ini, yakni sebagai berikut: (a) Bagaimana tingkat kesulitan belajar matematika pokok bahasan lingkaran pada siswa kelas VIII di MTs Swasta
Lhulo? (b) Apa saja faktor penyebab terjadinya kesulitan belajar matematika pokok bahasan lingkaran pada siswa kelas VIII di MTs Swasta Lhulo? (c) Apa saja upaya yang dilakukan untuk mengatasi kesulitan belajar matematika pokok bahasan lingkaran pada siswa kelas VIII di MTs Swasta Lhulo?

\section{TINJAUAN TEORETIS}

Menurut Mulyadi (2010), kesulitan belajar dapat diartikan sebagai suatu kondisi dalam suatu proses belajar yang ditandai adanya hambatan-hambatan tertentu untuk mencapai hasil belajar. Hambatanhambatan itu mungkin disadari dan mungkin juga tidak disadari oleh orang yang mengalaminya, dan dapat bersifat sosilogis, psikologis, ataupun fisiologis dalam keseluruhan proses belajarnya.

Kesulitan belajar siswa mencangkup pengertian yang luas, di antaranya (Yudhawati \& Haryanto, 2011):

a. Belajar yang tak teratur (learning disolder)

b. Belajar yang tidak banyak berfungsi (learning disfunction)

c. Belajar yang sekedar menerima materi belaka (underachiever learning)

d. Belajar lambat pikir (slow learner)

e. Belajar tanpa mempertimbangkan banyak kemungkinan (learning disabilities).

Banyak sudah para ahli yang mengemukakan faktor- faktor penyebab kesulitan belajar dengan sudut pandang mereka masing- masing. Ada yang meninjau dari sudut intern anak didik dan ada yang meninjau dari 
sudut ekstern anak didik (Djamarah, 2002). Menurut Syah (1999), faktorfaktor anak didik meliputi gangguan atau kekurangmampuan psiko-fisik anak didik, yaitu sebagai berikut:

a. Yang bersifat kognitif (ranah cipta), antara lain seperti rendahnya kapasitas intelektual/inteligensi anak didik.

b. Yang bersifat afektif (ranah rasa), antara lain seperti labilnya emosi dan sikap.

c. Yang bersifat psikomotor (ranah karsa), antara lain seperti terganggunya alat- alat indera penglihatan dan pendengaran (mata dan telinga).

Sedangkan faktor- faktor ekstern anak didik meliputi semua situasi dan kondisi lingkungan sekitar yang tidak mendukung aktivitas belajar anak didik, sebagai berikut (Syah, 2010):

a. Lingkungan keluarga, contohnya: ketidakharmonisan hubungan antara ayah dan ibu, dan rendahnya kehidupan ekonomi keluarga.

b. Lingkungan masyarakat, contohnya: wilayah perkampungan kumuh (slum area) dan teman sepermainan (peer group) yang nakal.

c. Lingkungan sekolah, contohnya: kondisi dan letak gedung sekolah yang buruk, kondisi guru serta alatalat belajar yang berkualitas rendah.

Sebelum menetapkan alternatif pemecahan masalah kesultan belajar siswa, guru sangat dianjur untuk terlebih dahulu melakukan identifikasi (upaya mengenali gejala dengan cermat) terhadap fenomena yang menunjukkan kemungkinan adanya kesulitan belajar yang melanda siswa tersebut. Upaya seperti ini disebut diagnosis yang bertujuan menetapkan “jenis penyakit" yakni jenis kesulitan belajar siswa.

Dalam melakukan diagnosis diperlukan adanya prosedur yang terdiri atas langkah-langkah tertentu yang diorentasikan pada ditemukannya kesulitan belajar jenis tertentu yang dialami siswa. Prosedur seperti ini dikenal sebagai "diagnostik" kesulitan belajar. Menurut Ahmadi dan Supriyono (2013), diagnosis dapat berupa hal-hal sebagai berikut:

1. Keputusan mengenai jenis- jenis kesulitan belajar anak (berat dan ringannya).

2. Keputusan mengenai faktor-faktor yang ikut menjadi penyebab kesulitan belajar.

3. Keputusan mengenai faktor utama penyebab kesulitan belajar.

Diagnosis kesulitan belajar dimaksudkan untuk mengetahui tingkat kesulitan belajar peserta didik. Kesulitan belajar dapat dibedakan menjadi kesulitan ringan, sedang dan berat (Mustika, 2016).

1. Kesulitan belajar ringan biasanya dijumpai pada peserta didik yang kurang perhatian di saat mengikuti pembelajaran.

2. Kesulitan belajar sedang dijumpai pada peserta didik yang mengalami gangguan belajar yang berasal dari luar diri peserta didik, misalnya faktor keluarga, lingkungan tempat tinggal, pergaulan, dsb.

Kesulitan belajar berat dijumpai pada peserta didik yang mengalami 
ketunaan pada diri mereka, misalnya tuna rungu, tuna netra suna daksa, dsb.

\section{METODOLOGI PENELITIAN}

Penelitian ini termasuk ke dalam penelitian deskriptif, yakni suatu bentuk penelitian yang paling dasar. Penelitian ini menggunakan pendekatan kualitatif. Moelong (2011) menyatakan bahwa pada pendekatan kualitatif,instrunen yang digunakan adalah peneliti sendiri. Peneliti merupakan perencana tindakan, pengumpul data, penganalisa data dan pelopor hasil penelitian (Nasution, 2018). Peneliti kemudian menganalisis kesulitan belajar siswa secara bijak dan mendalam.

Informan kunci dalam penelitian ini adalah siswa kelas VIII MTs Swasta Lhulo Kecamatan Bukit Kerman. Sedangkan informan pendukung adalah kepala sekolah, guru dan seluruh siswa yang terdiri dari 3 kelas yakni kelas VII, VIII dan kelas IX MTs Swasta Lhulo Kecamatan Bukit Kerman. Yang menjadi sumber data primer adalah siswa kelas VIII MTs Swasta Lhulo, sedangkan yang menjadi sumber data sekunder adalah literatur mengenai data-data objektif keadaan MTs Swasta Lhulo yang meliputi sejarah, visi, misi, tujuan serta keadaan sarana dan prasarana di sekolah ini.

Peneliti menggunakan metode observasi, wawancara, angket, dan dokumentasi untuk mengumpulkan data. Data yang didapat kemudian dianalisis dengan menggunakan analisis data kualitatif model interaktif Miles dan Huberman yang terdiri dari:
Reduksi data, Penyajian data, dan mengajukan kesimpulan / verifikasi.

\section{HASIL DAN PEMBAHASAN}

Hasil penelitian ini menunjukkan bahwa tingkat kesulitan belajar rendah dalam mata pelajaran matematika lebih banyak yaitu 61 (52\%) dari pada jumlah siswa yang mengalami kesulitan belajar tinggi dalam mata pelajaran matematika. $\mathrm{Hal}$ ini kemungkinan disebabkan karena siswa mengalami kesulitan belajar matematika dari aspek intern maupun ekstern. Dari aspek intern, (a) siswa kurang mempunyai minat dalam belajar matematika sebab siswa menganggap matematika sulit untuk dipelajari; (b) siswa juga kurang mempunyai motivasi untuk dapat berperan aktif di dalam kelas maupun di luar kelas dengan bertanya ketika siswa sulit memahami materi dan tugas. (c) siswa tidak mengikuti mata pelajaran matematika dengan penuh perhatian sehingga sulit untuk menerima dan mengingat materi yang diberikan guru; (d) siswa kurang berlatih dan mendiskusikan dengan teman ketika belum mengerti materi yang sudah diajarkan guru; (e) siswa juga kesulitan belajar jika menghadapi bahan pelajaran matematika yang terlalu banyak. Sedangkan dari aspek ekstern, (a) metode mengajar guru kurang jelas dan menarik bagi siswa; (b) kurangnya perlengkapan belajar siswa seperti buku wajib, buku penunjang, alat-alat tulis, dan kalkulator; (c) keadaan orang tua yang kurang memperhatikan anak saat belajar matematika di rumah; (d) siswa 
merasa kesulitan dengan bahan pelajaran yang terlalu banyak.

Siswa yang mengalami kesulitan belajar lebih tinggi sedikit jumlahnya yaitu 57 (48\%). Hal ini kemungkinan disebabkan dari aspek intern dan ekstern: dari aspek intern (a) siswa dengan cepat mempunyai keberanian mengerjakan soal-soal matematika yang diberikan oleh guru di papan tulis; (b) siswa juga teliti dan cermat dalam mengerjakan soal-soal matematika; (c) siswa berperan aktif di dalam kelas dan mau bertanya kepada guru ketika sulit memahami tugas matematika yang diberikan; (d) siswa mendengarkan penuh perhatian petunjuk untuk mengerjakan tugas metematika yang diberikan guru

Kesulitan belajar matematika di segi minat dipengaruhi oleh aspek intern dan aspek ekstern. Dari aspek intern, seperti: hilangnya dorongan belajar siswa untuk mengikuti pelajaran matematika. Dari aspek ekstern, seperti: kurangnya perhatian dari orang tua untuk mendukung kegiatan belajar siswa, penyajian materi oleh guru matematika yang dirasakan oleh siswa kurang menarik dan kurang bervariasi sehingga siswa kurang terdorong untuk berpartisipasi aktif dalam kegiatan pembelajaran.

Kesulitan belajar matematika di segi motivasi dapat dipengaruhi dari aspek intern dan aspek ekstern. Dari aspek intern, seperti: kurangnya semangat untuk belajar di kelas sehingga siswa selalu timbul rasa bosan terhadap pelajaran matematika. Kurangnya kesiapan dan kemauan siswa untuk mempelajari mata pelajaran matematika. Sedangkan dari aspek ekstern, siswa kurang memperhatikan guru dan siswa takut bertanya bila mengalami kesulitan dalam memahami materi tersebut sehingga siswa akan tertinggal dengan teman-temannya yang ikut bepartisipasi aktif dalam pelajaran.

Keadaan ini akan membuat siswa merasa tidak mempunyai motivasi untuk mencapai tujuan dalam hidupnya di kemudian hari. Kesulitan belajar matematika di segi intelegensi. Dalam bidang matematika siswa mempunyai kemampuan yang cukup. Hal ini membuktikan bahwa ada siswa yang bisa menguasai materi dan ada yang kurang menguasai pelajaran matematika. Siswa yang mengalami kesulitan untuk mengingat materi pelajaran matematika ini membutuhkan waktu lama dalam mengerjakan soalsoal matematika. Siswa juga tidak dengan mudah dapat mengerjakan soalsoal matematika yang terdapat dalam buku mata pelajaran matematika.

Kesulitan belajar matematika di segi bakat disebabkan kurangnya siswa untuk berlatih dalam memecahkan soal-soal matematika. Mata pelajaran matematika perlu usaha yang tinggi dari siswa untuk berlatih menggunakan rumus-rumus dalam menghitung, berlatih menggambar bangun ruang, dan berlatih menghitung luas bangun ruang dengan menggunakan rumus. Siswa yang mempunyai bakat dalam mata pelajaran matematika akan menggunakan teknik-teknik tertentu untuk memecahkan soal matematika. Untuk bisa terealisasi bakatnya maka harus ditunjang dengan minat, 
pengetahuan, pengalaman dan

perlengkapan belajar yang memadai agar bakat tersebut dapat berhasil dengan baik.

\section{Faktor Penyebab Terjadinya Kesulitan Belajar Matematika Pokok Bahasan Lingkaran Pada Siswa Kelas VIII di MTs Swasta Lhulo}

Dari hasil penelitian yang telah kami lakukan, bahwa penyebab kesulitan belajar matematika pokok bahasan lingkaran pada siswa kelas VIII di MTs Swasta Lhulo berasal dari beberapa faktor, antara lain faktor lembaga sekolah, guru, lingkungan masyarakat, orang tua dan faktor dari siswa itu sendiri.

Faktor penyebab kesulitan belajar matematika pokok bahasan lingkaran pada siswa kelas VIII di MTs Swasta Lhulo, antara lain:

Faktor-faktor kesulitan belajar siswa dalam mata pelajaran matematika yang intern antara lain:

a. Tingkat intelegensi siswa kurang, hal ini dibuktikan dengan hasil penelitian bahwa penyebab kesulitan belajar matematika pokok bahasan lingkaran pada siswa kelas VIII di MTs Swasta Lhulo adalah kemampuan siswa yang terbatas.

b. Siswa kurang mampu memahami keterangan yang diberikan oleh guru matematika.

c. Siswa kurang memotivasi diri untuk belajar

d. Siswa tidak dapat menerapkan materi pelajaran yang diterima di sekolah dalam kehidupan sehari-hari
Faktor ekstern penyebab kesulitan belajar matematika pokok bahasan lingkaran pada siswa kelas VIII di MTs Swasta Lhulo antara lain:

a. Faktor lembaga sekolah

Kesulitan belajar yang dialami siswa dapat disebabkan oleh faktor lembaga sekolah, hal ini dapat disebabkan oleh fasilitas yang dimiliki sekolah yang kurang memadai atau menunjang kegiatan belajar atau kurangnya sarana prasarana sekolah, seperti alat-alat belajar kurang lengkap, media pendidikan yang kurang sempurna, baik dari segi kualitas maupun kuantitas.

Sedangkan lingkungan sekolah sendiri dari hasil pengamatan yang peneliti lakukan, lingkungan MTs Swasta Lhulo sudah sangat menunjang pendidikan disekolah tersebut, hal ini dikarenakan banyaknya lembaga sekolah lain yang tempatnya berdekatan dengan MTs Swasta Lhulo, sehingga mau tidak mau MTs Swasta Lhulo harus mampu menyesuaikan dan berusaha menyamakan diri dengan Sekolahan lain.

b. Faktor orang tua

Sebagaimana yang telah dikatakan di atas bahwa siswa-siswi MTs Swasta Lhulo mayoritas berasal dari lingkungan petanir, sehingga keadaan keluarga kurang mendukung pendidikan anaknya. Kebanyakan dari orang tua siswa kurang memperhatikan belajar anak ataupun kebutuhan belajar anaknya, seperti halnya memenuhi kebutuhan alat-alat belajar. Ini juga disebabkan 
karena mayoritas pendidikan orang tua siswa relatif rendah.

c. Faktor anak sendiri

Kesulitan belajar yang dialami siswa bisa dikarenakan oleh siswa sendiri yang kurang memotivasi dirinya untuk giat belajar, juga dikarenakan intelegensi yang dimiliki siswa kurang, sehingga dapat menyebabkan siswa tidak dapat menerima pelajaran dengan sempurna.

\section{Upaya Mengatasi Kesulitan Belajar Matematika Pokok Bahasan Lingkaran Pada Siswa Kelas VIII di MTs Swasta Lhulo}

Dalam proses belajar mengajar seorang siswa dituntut untuk dapatmemahami dan bisa menerapkan apa yang telah disampaikan olehgurunya. Tetapi kadang-kadang seorang siswa ada yang masih kesulitandalam belajarnya. Ini disebabkan oleh beberapa faktor, baik dari lembagasekolah, guru, keluarga, orang tua dan diri siswa itu sendiri. Siswamengalami kesulitan atau hambatan dalam belajar itu merupakan suatu halyang wajar, sekarang yang terpenting adalah bagaimana caramenanggulangi kesulitan belajar khususnya pada mata pelajaran matematika yangdialami oleh siswa sehingga tujuan pembelajaran dapat tercapaisecara optimal.Begitu juga di MTs Swasta Lhulo sebagaimana yang telahdikatakan oleh guru matematika bahwa selama ini di di MTs Swasta Lhulo kadang-kadang ada siswa yang mengalami kesulitanbelajar matematika, dan selama itu juga pihak lembagasekolah dan guru selalu berusaha menanggulanginya. Upaya yangdilakukan oleh di MTs Swasta Lhulo ada dua jalan antara lain:

a. Upaya dari pihak siswa sendiri (intern)

Dalam usaha menanggulangi kesulitan belajar yang dialamiya, siswa melakukan beberapa hal antara lain: berusaha mengoptimalkan kemampuan yang dimiliki dengan jalan belajar yang sungguh-sungguh atau belajar kelompok, membuat jadwal belajar, dan menumbuhkan keinginan untuk mencapai cita-cita, serta berusaha menerapkan materi pelajaran dalam kehidupan sehari-hari.

b. Upaya dari luar (ekstern)

1) Dari pihak sekolah

Memenuhi sarana dan prasarana pendidikan, mengadakan pertemuan dengan komite sekolah dengan wali siswa dalam rangka menanggulangi kesulitan belajar matematika siswa, mendatangkan nara sumber bila ada kegiatan belajar yang membutuhkan tenaga professional, memberikan bimbingan kepada siswa-siswi yang mengalami kesulitan belajar matematika, serta guru mengadakan kunjungan kerumah siswa.

2) Dari pihak guru

Meningkatkan pengetahuan dengan mengikuti penataranpenataran dan perkuliahan, memberi jam tambahan pelajaran (kurikuler), menggunakan metode dan media pembelajaran yang dimiliki pihak sekolah dalam kegiatan pembelajaran matematika, membentuk kelompok belajar siswa, 
dalam proses belajar mengajar guru menciptakan suasana yang dapat membuat siswa senang pada pelajaran yang diberikan oleh guru matematika. Jika terdapat siswa yang mengalami kesulitan belajar matematika, guru berusaha membantu siswa memecahkan persoalan yang dihadapinya agar masalahnya dapat segera terpecahkan, salah satunya dengan memberikan bimbingan secara khusus kepada siswa yang menagalami kesulitan belajar.

3) Dari pihak keluarga

Menciptakan situasi keluarga yang harmonis, berusaha lebih memperhatikan anak, khususnya dalam hal belajar matematika, berusaha memperbaiki ekonomi keluarga agar dapat memenuhi kebutuhan belajar anak, sehingga anak lebih termotivasi melakukan kegiatan belajar. Orang tua siswa dalam upayanya menanggulangi kesulitan belajar matematika yang dialami anaknya, mereka berusaha memotivasi anak dalam belajar dan memberi bimbingan semampunya dan jika ada undangan sekolah kepada wali siswa, mereka berusaha menghadiri untuk membicarakan masalah-masalah belajar anaknya, selain itu juga orang tua siswa berusaha kebutuhan belajar anaknya. Upaya menanggulangi kesulitan belajar pendidikan matematika siswa juga dilakukan oleh siswa sendiri, yaitu antara lain dengan lebih giat belajar, membuat jadwal belajar agar dapat belajar dengan teratur, melakukan belajar kelompok bersama teman-temannya dengan belajar kelompok siswa memecahkan permasalahan dengan cara diskusi bersama temantemannya. Dan jika dalam belajar siswa mengalami kesulitan yang tidak dapat dipecahkannya, siswa dapat bertanya kepada orang tua, guru dan temannya.

\section{SIMPULAN DAN SARAN}

Tingkat kesulitan belajar matematika pokok bahasan lingkaran pada siswa kelas VIII di MTs Swasta Lhulo tergolong rendah karena jumlah siswa yang mengalami tingkat kesulitan belajar rendah dalam mata pelajaran matematika sebanyak 61 (52\%) sedangkan siswa yang mengalami kesulitan belajar tinggi dalam mata pelajaran matematika sebanyak 57 (48\%), sehingga dapat disimpulan bahwa jumlah siswa yang mengalami kesulitan rendah dalam mata pelajaran matematika lebih banyak dari pada jumlah siswa yang mengalami kesulitan belajar tinggi dalam mata pelajaran matematika.

Faktor penyebab terjadinya kesulitan belajar matematika pokok bahasan lingkaran pada siswa kelas VIII di MTs Swasta Lhulo yakni: kurangnya penggunaan media pembelajaran, penerapan metode yang kurang tepat, kurang terpenuhinya kebutuhan belajar, rendahnya tingkat intelegensi siswa, dan rendahnya motivasi siswa dalam belajar matematika.

Upaya mengatasi kesulitan belajar matematika pokok bahasan lingkaran pada siswa kelas VIII di MTs 
Swasta Lhulo, diantaranya ialah membuat jadwal belajar di rumah, memberikan bimbingan pada siswa, menggunakan metode bervariasi, menggunakan metode belajar tuntas dan penggadaan fasilitas penunjang.

Dari hasil penelitian yang diperoleh, maka peneliti memberikan saran sebagai berikut (1) Siswa diharapkan untuk terus meningkatkan minat dan motivasi belajar matematika secara kontinu dan banyak latihan soal matematika sehingga akan memperluas pandangan terhadap berbagai masalah matematika. Sebab matematika penting untuk dipelajari. (2)Guru mata pelajaran matematika perlu membangkitkan minat dan motivasi siswa untuk belajar matematika dengan melibatkan siswa secara langsung dalam proses belajar mengajar sehingga dapat menumbuhkan dorongan untuk belajar. Serta guru hendaknya lebih meningkatkan metode pengajaran yang lebih bervariasi sehingga dapat membangkitkan belajar siswa di kelas. (3) Hendaknya orang tua lebih memperhatikan anaknya, terutama masalah belajarnya. Juga berusaha memenuhi kebutuhan belajar anaknya. Membantu memecahkan masalah jika anak mendapatkan masalah yang bisa mempengaruhi kegiatan belajarnya, lebih memotivasi anak dalam belajar, mengawasi anak dalam belajarnya, dan menyediakan fasilitas belajar.

\section{DAFTAR PUSTAKA}

Ahmadi, Abu dan Supriyono, Widodo. (2013). Psikologi Belajar. Jakarta Rineka Cipta.
Djamarah, Syaiful Bahri. (2002). Psikologi Belajar. Jakarta : Rineka Cipta.

Hudojo, Herman. (2005). Pengembangan Kurikulum dan Pembelajaran Matematika. Malang: UM Press.

Moleong, L. J., (2011), Metodologi Penelitian Kualitatif,. Bandung: Remaja Rosdakarya.

Muhibin, Syah. (2010). Psikologi Pendidikan dengan Pendekatan Baru. Bandung: Remaja Rosdakarya.

Mustika, T. (2016). Psikologi Pendidikan. Lampung: Program Studi Pendidikan Ekonomi STKIP Kumala Lampung.

Nasution, E. Y. P. (2018). Analisis Terhadap Disposisi Berpikir Kreatif Siswa Pada Pembelajaran Matematika. Edumatika: Jurnal Riset Pendidikan Matematika, 1(1), 44-55.

Nasution, E. Y. P., Penbrianti, D., \& Putri, R. (2020). Analisis Terhadap Disposisi Berpikir Kritis Siswa Jurusan IPS Pada Pembelajaran Matematika. Mathline: Jurnal Matematika dan Pendidikan Matematika, 5(1), 61-76.

Sardiman, A.M. (2001). Interaksi dan Motivasi Belajar Mengajar. Jakarta : Raja Grafindo Persada.

Syah, Muhibbin. (1999). Psikologi Belajar. Jakarta : PT. Logos Wacana Ilmu.

Yudhawati, Ratna dan Haryanto, Dany. (2011) Teori-Teori dasar Psikologi Pendidikan, Jakarta : Prestasi Pustakaraya. 